\title{
Gender differences in prevalence of diagnosed type 2 diabetes and patient's body mass index in five Ukraine regions with diverse historical backgrounds
}

\author{
Mykola D. Khalangot $^{1 *}$, Vitaliy G. Gurianov ${ }^{2}$, Alexander M. Vaiserman ${ }^{3}$ \\ ${ }^{1}$ Department of Endocrinology, P.L. Shupyk National Medical Academy of Postgraduate Education. \\ Vyshgorodska 69, Kiev 04114, Ukraine. \\ ${ }^{2}$ M. Gorky Donetsk National Medical University, Donetsk, Ukraine. \\ ${ }^{3}$ D.F. Chebotarev Institute of Gerontology, Academy of Medical Sciences, Kiev, Ukraine. \\ Corresponding author: M. D. Khalangot (ه)
}

doi:10.5618/bio.2012.v2.n1.1 || Received: 03-01-2012, Accepted: 23-01-2012, Available online: 28-01-2012

\begin{abstract}
Analysis of territorial diabetes mellitus registers of 2 Western and 3 Eastern Ukraine regions with diverse historical backgrounds was performed. Two western regions (Kherson and Crimea) were severely affected by Famine of 1932-33, Chernihiv region was less severely affected area, and Western-Ukraine regions (Volyn and Rivne) were not affected. Prevalence rates of diagnosed type 2 diabetes mellitus (T2D) in women are higher than in men in all birth cohorts studied except for the oldest ones. The female-to-male predominance is more pronounced for people with T2D residing in Eastern Ukraine regions. Female (but not male) persons with T2D residing in Eastern Ukraine have higher body mass index than those residing in Western Ukraine. Female predominance among persons with T2D in Ukraine may be due to the fact that women are more likely than men to be influenced by adverse early-life conditions.
\end{abstract}

Keywords: Body mass index; Developmental programming; Gender differences ; Great Ukrainian Famine of 1932-33; Type 2 diabetes

\begin{tabular}{|c|c|}
\hline \multicolumn{2}{|c|}{ Abbreviations } \\
\hline BMI & Body mass index \\
\hline CI & Confidence interval \\
\hline $\mathrm{T} 2 \mathrm{D}$ & Type 2 diabetes \\
\hline OR & Odds ratio \\
\hline
\end{tabular}

\section{Introduction}

The prevalence of diabetes mellitus is growing worldwide and could reach pandemic proportions in the near future [1]. It is a recognized global health problem, especially in developing countries. According to the analysis by Shaw et al. [2], between 2010 and 2030 , there will be a $20 \%$ increase in numbers of adults with diabetes in developed countries and a $69 \%$ increase in developing countries. Presently, the earlylife circumstances are considered to be the most important causal factors in the development of type 2 diabetes (T2D) and other metabolic disorders [3, 4]. The 'thrifty genotype' and 'thrifty phenotype' hypotheses have been forward to explain the link between early life environment and subsequent development of metabolic syndrome and associated chronic diseases. The 'thrifty genotype' hypothesis was proposed by Neel [5] to explain the increasing incidence of diabetes in the Western World. Neel hypothesized that to ensure survival during periods of famine, certain genes that favor excess storage of fat evolved to regulate efficient intake and utilization of fuel stores. However, these genes that improve survival during famine can become detrimental when food supply become abundant, thus explaining the association between malnutrition and later development of metabolic complications. According to the 'thrifty phenotype' hypothesis proposed more recently by Hales and Barker [6], poor fetal nutrition results in permanent changes in glucose-insulin metabolism (insulin hypersecretion as the primary event, and insulin resistance the response) that, together with other hormonal and metabolic adaptations, help survival in poor postnatal conditions. These alterations are beneficial to survival in a poor nutritional environment, but may lead to diabetes and other features of the metabolic syndrome if the postnatal environment conflicts with the earlier programming (e.g., if postnatal nutrition is abundant) and obesity occurs in adult life. It is becoming increasingly apparent that epigenetics (which refers to any process that alters gene activity without changing the actual DNA se- 
quence) may bridge both the 'thrifty genotype' and 'thrifty phenotype' hypotheses and provide a link between genes and the environment concerning disease predisposition to metabolic syndrome and related diseases [7, 8].

The early life conditions may likely contribute to gender differences in T2D prevalence. In the first half of the 20th century, a pronounced female excess in T2D was evident in USA and Europe. Presently, T2D is equally prevalent in men and women in most Western populations, with some evidence of male preponderance in early middle age [9]. The opposite pattern prevails in developing countries: the prevalence of obesity and T2D are higher in women compared to men [10-13]. Such gender differences can be at least partly explained by the secular trend in socioeconomic conditions in developed countries. It is well established that the adverse socioeconomic conditions in early life can profoundly affect individual development and produce lasting increases in the risk of metabolic and cardiovascular disease later in life [14]. Socioeconomic status likely is an important factor in developing T2D, especially for women $[15,16]$. For example, in Hong Kong Chinese, the age-adjusted odds ratio of having diabetes was 4.5 (1.9-10.9) in female subjects with the lowest socioeconomic status compared to those with the highest socioeconomic status; the corresponding age-adjusted odds ratio in male subjects was 1.9 (0.9-3.9) but this was not statistically significant [17]. Among residents of China's poor rural areas (Tianjin province), the prevalence of impaired fasting glucose, screen-detected diabetes and previously diagnosed diabetes was significantly higher in women than in men [18].

Taken together, these findings may explain a female excess in T2D prevalence in countries with poor economics. Ukraine is among such countries. During the first half of the XX century, Eastern Ukraine has thrice suffered famine (in 1921-1923, 1932-1933, and 1946-1947) and thrice was the area of famineassociated social conflicts (World War I 1914-18 followed by Russian revolution and civil war, 19181920, and World War II 1941-1944). Unlike Eastern Ukraine, Western Ukraine was under Polish rule until 1939, and joined the Soviet Union following a pact with Germany to divide Poland (Fig. 1). Western and Eastern Ukraine population are similar ethnically, and have similar diet habits and lifestyle, but people from Eastern Ukraine only was suffered from Sovietinduced social troubles during the interwar period. Thus, the comparison between Western and Eastern Ukraine cohorts born during this period can provide information about the role of severe adverse events in early life on later population health perspective including gender-related risk of developing T2D. However, the evaluation of gender differences in the risk of developing T2D was never performed in Ukraine excepting Tronko et al. study [19] where excess risk was observed among insulin-treated T2D women. The aim of this large-scale population-based study was to investigate the gender differences in anthropometric status and prevalence of all diagnosed T2D in five Western and Eastern Ukraine regions with diverse historical backgrounds.

\section{Materials and methods.}

2.1 Study population. Information on date of birth, sex, height, weight and year of diabetes diagnosis was extracted from the nationwide population-based Ukrainian diabetes register (SINADIAB, created in 2000, last updated in March 14, 2008) in V.P. Komisarenko Institute of Endocrinology and Metabolism, Academy of Medical Sciences, Kiev, Ukraine. The reports of primary care doctors from the entire country were used as the primary data source in creating the register. World Health Organization (WHO) 1999 criteria were used to define diabetes mellitus. The study protocol has been approved by the ethics committee of the V.P. Komisarenko Institute of Endocrinology and Metabolism.

To minimize bias due to misclassification of diabetes type, cases were restricted to persons born before 1965 and diagnosed with T2D after age 39. Cases were identified from the five Ukraine regional diabetes registers with high completeness of ascertainment. Three regions represented the Eastern Ukraine: Chernihiv (completeness: 100\%), Kherson (completeness: 99.0\%) and Crimea (completeness: 100\%), and two represented the Western Ukraine: Volin (completeness: 100\%) and Rivne (completeness: 88.6\%). These regions have different historical background. The residents of the Eastern Ukraine were exposed to the Great Famine of 1932-33, and the residents of the Western Ukraine were not exposed to this sociallyinduced disaster. Among five regions studied, two regions (Kherson and Crimea) were severely affected by Famine of 1932-33 (rate of population decline during 1929-33 was 20-25\%) [20], Chernihiv region was less severely affected area (rate of population decline was up to $15 \%$ ), and Western-Ukraine regions (Volyn and Rivne) were not affected. The total population residing in these regions is estimated at 6 380500 (according to the Statistical Yearbook of the State Statistics Committee of Ukraine, 2006). Data on date of birth, sex and year of diagnosis were missing in these regional registers for 11688 individuals. Complete data to estimate T2D prevalence were available for 105374 subjects (34 415 men and 70 959 women) residing in these regions. Among them, there were 23575 men and 51769 women residing in Eastern Ukraine regions, and 10840 men and 19190 women residing in Western Ukraine regions studied. Data on height and weight were missing among these subjects for 10914 individuals, accordingly, BMI was determined for 94460 persons. Information about the 
blood glucose-lowering therapy was available for most patients (29 706 T2D persons in Western Ukraine regions and 73235 T2D persons in Eastern Ukraine regions studied). Information about the number of insulin-treated patients (1552 men and 2183 women in Western Ukraine regions and 4347 men and 8531 women in Eastern Ukraine regions, $12.6 \%$ and $17.6 \%$ among all $\mathrm{T} 2 \mathrm{D}$ patients, respecttively) was considered as most reliable, since the determination of the insulin requirement in diabetic patients was the initial aim of the register.

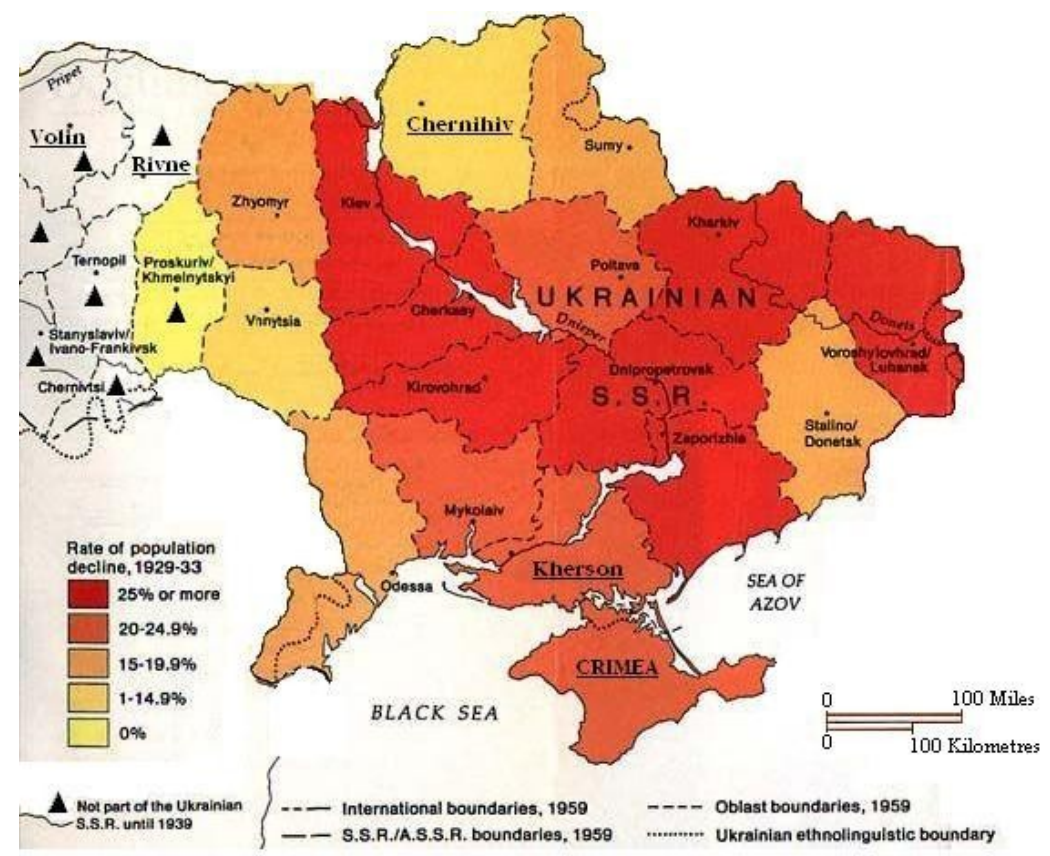

Fig. 1. The map of the Ukraine Famine of 1933 area. Adapted and redrawn from [20]. Five studied Ukraine regions, among them two Western-Ukraine regions [Volin (former Lutsk) and Rivne] and three Eastern-Ukraine regions (Chernihiv, Kherson and Crimea) are marked by the underlined font.

The anthropometric data from the SINADIAB register were also used in our previous epidemiological study [21]. Data about the sample sizes in reference populations were extracted from the Statistical Yearbook of the State Statistics Committee of Ukraine [22]. These populations consisted of people who had been born during the same period and are residents of the same regions: Crimea: 390711 men and 547525 women, Kherson: 218384 men and 298589 women, Chernihiv: 244031 men and 356632 women, Volin: 186990 men and 253803 women, Rivne: 203604 men and 270611 women.

2.2 Statistical analysis. The prevalence rates of T2D were calculated as percentages of the total study population, stratified by birth cohort, gender and region. Confidence intervals (CIs) for prevalence rates were calculated with the normal approximation to the binomial distribution. To evaluate the gender differences in the risk of developing $\mathrm{T} 2 \mathrm{D}$, female/ male odds ratios (ORs) and corresponding 95\% CIs were calculated by a logarithmic transformation [23]. $P$ values were determined by the Fisher's exact test. Due to the large sample sizes, statistical significance was set at $P<0.001$. Body mass index (BMI) for each person was determined as the actual body weight divided by the square of height $\left(\mathrm{kg} / \mathrm{m}^{2}\right)$. Median BMIs and corresponding $95 \%$ CIs were calculated for subpopulations stratified by gender, area of residence and birth cohort. Statistical differences between populations were assessed by Mann-Whitney U test. Most of analyses were performed using SPSS software (Windows ver. 11.0; SPSS Inc., Chicago, IL). Data, presented on Fig.2 was calculated using MedStat (Windows ver. 4.1; Yu. Lyakh, V. Gurianov, Certificate of Authorship 1058, Ukraine, 2004-2011).

\section{Results}

In Ukraine areas studied, T2D prevalence rate is higher for women $(3.9 \%)$ than for men $(2.7 \%)$, female/male OR $=1.48$ (95\% CI: 1.46-1.50), $P<$ 0.0001 . During the period studied, prevalence rates are steadily increasing with age in both sexes, reached a peak in the 1940-44 birth cohort in Western Ukraine regions and in the 1930-34 birth cohort in Eastern Ukraine regions; in more advanced ages, however, the 


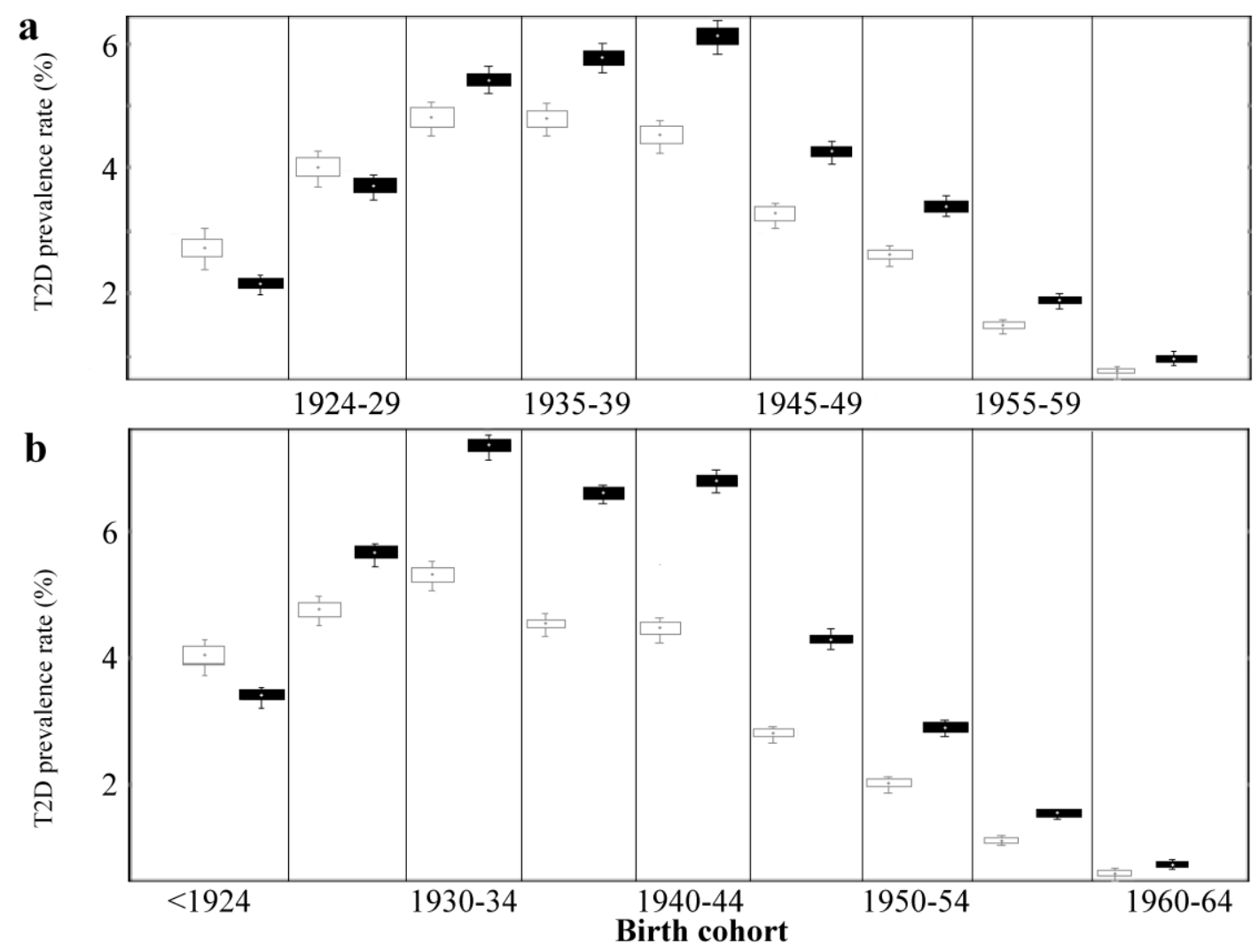

Fig. 2 Prevalence rates of Type 2 diabetes in persons aged 40 years and older residing in Western-Ukraine regions (a) and Eastern-Ukraine regions (b), by gender and birth cohort. Each box-and-whisker plot shows the prevalence percentage (the dot within the box), standard error (the upper and lower margins of the box), and 95\% confidence interval (the whiskers outside the box). Black boxes, women; white boxes, men.

trend becomes opposite (Fig. 2). These data are consistent with data from different populations worldwide which show an increase in the prevalence of T2D with increasing age, with values reaching a plateau or even declining in very old age [24]. The decrease in T2D prevalence in oldest age groups may be because persons with diabetes mellitus have a lower life expectancy than those without the disease. As we can see from Fig. 1, T2D prevalence rates in women are higher than in men in all birth cohorts except for the earliest ones $(\leq 1924$ and 1925-29 birth cohorts in Western Ukraine regions, and 1925-29 birth cohort in Eastern Ukraine regions), when prevalence in men becomes higher. The female-to-male predominance is more pronounced for people with T2D residing in Eastern Ukraine regions [female/male OR $=1.55$ (95\% CI: 1.53-1.58)] compared to those residing in Western Ukraine regions [female/male OR $=1.32$ (95\% CI: 1.29-1.35)]. In both Western Ukraine regions studied, the female preponderance is evident in most birth cohorts except for the eldest ones, namely, for persons born after 1934 (Tables 1 and 2). In Eastern Ukraine regions, the female predominance was found in the earlier cohorts, namely, for persons born after 1924 in Kherson and Crimea regions, and after 1929 in Chernihiv region (Table 3).

Similar trends were found with regard to BMI. A significant effect of region of residence on BMI was detected in female but not in male T2D persons. The median BMI for those men with $\mathrm{T} 2 \mathrm{D}$ residing in Western Ukraine was 27.14 (95\% CI: 27.09-27.25) and for those residing in Eastern Ukraine was 27.24 (95\% CI: 27.16-27.33). Among women with T2D, those residing in Eastern Ukraine have higher median BMI (28.38; 95\% CI: 28.34-28.44) than those residing in Western Ukraine (27.91; 95\% CI: 27.83-27.96) at significance level $P<0.01$ by Mann-Whitney U-test. Such differences are evident in most birth cohorts studied (Fig. 3). 
Table 1. Numbers of cases and prevalence rates $[\mathrm{n} / \mathrm{N}(\%)]$ of male T2D in five Ukraine regions, by region of residence and birth cohort.

\begin{tabular}{|c|c|c|c|c|c|}
\hline \multirow{2}{*}{$\begin{array}{c}\text { Birth } \\
\text { cohort }\end{array}$} & \multicolumn{3}{|c|}{ Western Ukraine } & \multicolumn{2}{|c|}{ Eastern Ukraine } \\
\hline & Volin & Rivne & Chernihiv & Kherson & Crimea \\
\hline$\leq 1924$ & $\begin{array}{l}168 / 6307 \\
(2.7)\end{array}$ & $\begin{array}{l}179 / 6151 \\
(2.9)\end{array}$ & $\begin{array}{l}284 / 9934 \\
(2.9)\end{array}$ & $\begin{array}{l}251 / 4884 \\
(5.1)\end{array}$ & $\begin{array}{l}497 / 9841 \\
(5.1)\end{array}$ \\
\hline $1925-29$ & $\begin{array}{l}383 / 11154 \\
(3.4)\end{array}$ & $\begin{array}{l}516 / 10462 \\
(4.9)\end{array}$ & $\begin{array}{l}626 / 17740 \\
(3.5)\end{array}$ & $\begin{array}{l}621 / 10138 \\
(6.1)\end{array}$ & $\begin{array}{l}1127 / 19592 \\
(5.8)\end{array}$ \\
\hline $1930-34$ & $\begin{array}{l}583 / 14263 \\
(4.1)\end{array}$ & $\begin{array}{l}865 / 14520 \\
(6.0)\end{array}$ & $\begin{array}{l}743 / 16900 \\
(4.4)\end{array}$ & $\begin{array}{l}732 / 11722 \\
(6.2)\end{array}$ & $\begin{array}{l}1416 / 22786 \\
(6.2)\end{array}$ \\
\hline 1935-39 & $\begin{array}{l}754 / 15787 \\
(4.8)\end{array}$ & $\begin{array}{l}950 / 18297 \\
(5.2)\end{array}$ & $\begin{array}{l}1322 / 30636 \\
(4.3)\end{array}$ & $\begin{array}{l}1418 / 26752 \\
(5.3)\end{array}$ & $\begin{array}{l}2115 / 45243 \\
(4.7)\end{array}$ \\
\hline $1940-44$ & $\begin{array}{l}642 / 14999 \\
(4.3)\end{array}$ & $\begin{array}{l}843 / 16547 \\
(5.1)\end{array}$ & $\begin{array}{l}931 / 18833 \\
(4.9)\end{array}$ & $\begin{array}{l}897 / 18059 \\
(5.0)\end{array}$ & $\begin{array}{l}1320 / 30502 \\
(4.3)\end{array}$ \\
\hline $1945-49$ & $\begin{array}{l}815 / 23090 \\
(3.5)\end{array}$ & $\begin{array}{l}811 / 25441 \\
(3.2)\end{array}$ & $\begin{array}{l}1027 / 31410 \\
(3.3)\end{array}$ & $\begin{array}{l}862 / 29214 \\
(3.0)\end{array}$ & $\begin{array}{l}1335 / 51734 \\
(2.6)\end{array}$ \\
\hline $1950-54$ & $\begin{array}{l}696 / 28212 \\
(2.5)\end{array}$ & $\begin{array}{l}874 / 30683 \\
(2.8)\end{array}$ & $\begin{array}{l}861 / 38428 \\
(2.2)\end{array}$ & $\begin{array}{l}810 / 36375 \\
(2.2)\end{array}$ & $\begin{array}{l}1205 / 66099 \\
(1.8)\end{array}$ \\
\hline $1955-59$ & $\begin{array}{l}558 / 37642 \\
(1.5)\end{array}$ & $\begin{array}{l}635 / 41715 \\
(1.5)\end{array}$ & $\begin{array}{l}531 / 41755 \\
(1.3)\end{array}$ & $\begin{array}{l}473 / 40812 \\
(1.2)\end{array}$ & $\begin{array}{l}751 / 73654 \\
(1.0)\end{array}$ \\
\hline $1960-64$ & $\begin{array}{l}268 / 35536 \\
(0.8)\end{array}$ & $\begin{array}{l}300 / 39788 \\
(0.8)\end{array}$ & $\begin{array}{l}303 / 38395 \\
(0.8)\end{array}$ & $\begin{array}{l}249 / 40428 \\
(0.6)\end{array}$ & $\begin{array}{l}347 / 71260 \\
(0.5)\end{array}$ \\
\hline $\begin{array}{c}\text { Total } \\
\text { by region }\end{array}$ & $\begin{array}{l}4867 / 186990 \\
(2.6)\end{array}$ & $\begin{array}{l}5973 / 203604 \\
(2.9)\end{array}$ & $\begin{array}{l}6628 / 244031 \\
(2.7)\end{array}$ & $\begin{array}{l}6313 / 218384 \\
(2.9)\end{array}$ & $\begin{array}{l}10113 / 390711 \\
(2.6)\end{array}$ \\
\hline
\end{tabular}

$\mathrm{n}$ - T2D cases, $\mathrm{N}$ - population at risk, $\%$ - prevalence rate.

Table 2. Numbers of cases and prevalence rates $[\mathrm{n} / \mathrm{N}(\%)]$ of female T2D in five Ukraine regions, by region of residence and birth cohort.

\begin{tabular}{llllll}
\hline Birth cohort & Western Ukraine & Eastern Ukraine & \\
& Volin & Rivne & Chernihiv & Kherson & Crimea \\
\hline \multirow{2}{*}{$\begin{array}{l}\text { 1924 } \\
\text { (148/19112 }\end{array}$} & $504 / 19750$ & $776 / 38924$ & $877 / 18468$ & $1522 / 32896$ \\
& $(1.8)$ & $(2.6)$ & $(2.0)$ & $(4.7)$ & $(4.6)$ \\
$1925-29$ & $784 / 24814$ & $1045 / 22954$ & $1382 / 40411$ & $1685 / 23198$ & $3265 / 41976$ \\
& $(3.2)$ & $(4.6)$ & $(3.4)$ & $(7.3)$ & $(7.8)$ \\
$1930-34$ & $1272 / 26951$ & $1770 / 26199$ & $1659 / 29921$ & $1926 / 20836$ & $3596 / 39857$ \\
& $(4.7)$ & $(6.8)$ & $(5.5)$ & $(9.2)$ & $(9.0)$ \\
$1935-39$ & $1495 / 26983$ & $1945 / 29408$ & $2866 / 49781$ & $3113 / 41038$ & $5505 / 71511$ \\
& $(5.5)$ & $(6.6)$ & $(5.8)$ & $(7.6)$ & $(7.7)$ \\
$1940-44$ & $1187 / 20632$ & $1644 / 22929$ & $1779 / 27361$ & $2124 / 25987$ & $3212 / 44202$ \\
& $(5.8)$ & $(7.2)$ & $(6.5)$ & $(8.2)$ & $(7.3)$ \\
$1945-49$ & $1176 / 27383$ & $1395 / 30552$ & $1749 / 39452$ & $1806 / 36188$ & $2929 / 68491$ \\
& $(4.3)$ & $(4.6)$ & $(4.4)$ & $(5.0)$ & $(4.3)$
\end{tabular}


Table 2 ( to be continued)

\begin{tabular}{llllll}
\hline Birth cohort & Western kraine & \multicolumn{5}{c}{ Eastern Ukraine } \\
& Volin & Rivne & Chernihiv & Kherson & Crimea \\
\hline \multirow{2}{*}{$1950-54$} & $1008 / 31540$ & $1286 / 34079$ & $1351 / 43635$ & $1359 / 42960$ & $2271 / 81329$ \\
& $(3.2)$ & $(3.8)$ & $(3.1)$ & $(3.2)$ & $(2.8)$ \\
$1955-59$ & $666 / 39715$ & $925 / 44028$ & $789 / 46164$ & $779 / 46013$ & $1235 / 86913$ \\
& $(1.7)$ & $(2.1)$ & $(1.7)$ & $(1.7)$ & $(1.4)$ \\
$1960-64$ & $315 / 36673$ & $425 / 40712$ & $357 / 40983$ & $348 / 43901$ & $520 / 80350$ \\
Total & $(0.9)$ & $(1.0)$ & $(0.9)$ & $(0.8)$ & $(0.6)$ \\
by region & $8251 / 253803$ & $10939 / 270611$ & $12708 / 356632$ & $14017 / 298589$ & $24055 / 547525$ \\
\hline
\end{tabular}

Table 3. Female/male odds ratios (ORs) and corresponding 95\% confidence intervals (95\% CIs) for T2D patients, by region of residence and birth cohort.

\begin{tabular}{|c|c|c|c|c|c|}
\hline \multirow[t]{3}{*}{$\begin{array}{l}\text { Birth } \\
\text { cohort }\end{array}$} & \multicolumn{5}{|c|}{ Region of residence } \\
\hline & \multicolumn{2}{|c|}{ Western Ukraine } & \multicolumn{3}{|l|}{ Eastern Ukraine } \\
\hline & Volin & Rivne & Chernihiv & Kherson & Crimea \\
\hline$\leq 1924$ & $0.68(0.57-0.82)^{\mathrm{a}}$ & $0.88(0.74-1.04)$ & $0.70(0.61-0.80)^{\mathrm{a}}$ & $0.92(0.80-1.07)$ & $0.92(0.83-1.02)$ \\
\hline $1925-29$ & $0.92(0.81-1.04)$ & $0.92(0.83-1.03)$ & $0.97(0.88-1.07)$ & $1.19(1.08-1.30)^{\mathrm{b}}$ & $1.35(1.26-1.45)^{\mathrm{b}}$ \\
\hline 1930-34 & $1.16(1.05-1.28)$ & $1.13(1.04-1.23)$ & $1.26(1.15-1.38)^{\mathrm{b}}$ & $1.48(1.36-1.62)^{\mathrm{b}}$ & $1.45(1.36-1.55)^{\mathrm{b}}$ \\
\hline 1935-39 & $1.16(1.06-1.27)^{\mathrm{b}}$ & $1.27(1.18-1.38)^{\mathrm{b}}$ & $1.33(1.25-1.43)^{\mathrm{b}}$ & $1.43(1.34-1.53)^{\mathrm{b}}$ & $1.65(1.56-1.73)^{\mathrm{b}}$ \\
\hline $1940-44$ & $1.34(1.22-1.48)^{\mathrm{b}}$ & $1.41(1.29-1.53)^{\mathrm{b}}$ & $1.32(1.21-1.43)^{\mathrm{b}}$ & $1.65(1.52-1.78)^{\mathrm{b}}$ & $1.68(1.57-1.79)^{\mathrm{b}}$ \\
\hline $1945-49$ & $1.22(1.11-1.33)^{\mathrm{b}}$ & $1.43(1.31-1.56)^{\mathrm{b}}$ & $1.36(1.25-1.47)^{\mathrm{b}}$ & $1.69(1.56-1.84)^{\mathrm{b}}$ & $1.66(1.55-1.77)^{\mathrm{b}}$ \\
\hline $1950-54$ & $1.30(1.18-1.43)^{\mathrm{b}}$ & $1.33(1.21-1.45)^{\mathrm{b}}$ & $1.38(1.27-1.51)^{\mathrm{b}}$ & $1.42(1.30-1.55)^{\mathrm{b}}$ & $1.53(1.43-1.64)^{\mathrm{b}}$ \\
\hline $1955-59$ & $1.13(1.01-1.27)$ & $1.38(1.25-1.53)^{\mathrm{b}}$ & $1.34(1.20-1.50)^{\mathrm{b}}$ & $1.46(1.30-1.64)^{b}$ & $1.39(1.27-1.53)^{b}$ \\
\hline $1960-64$ & $1.14(0.97-1.34)$ & $1.39(1.19-1.61)^{\mathrm{b}}$ & $1.10(0.95-1.29)$ & $1.29(1.09-1.52)^{b}$ & $1.33(1.16-1.52)^{\mathrm{b}}$ \\
\hline $\begin{array}{l}\text { Total } \\
\text { by } \\
\text { region }\end{array}$ & $1.25(1.21-1.30)^{b}$ & $1.38(1.33-1.42)^{\mathrm{b}}$ & $1.31(1.27-1.35)^{\mathrm{b}}$ & $1.62(1.58-1.67)^{b}$ & $1.69(1.66-1.74)^{\mathrm{b}}$ \\
\hline
\end{tabular}

${ }^{a} P<0.001$ by the left-tailed Fisher's exact test to test if the odds ratio is significantly less than 1

${ }^{\mathrm{b}} P<0.001$ by the right-tailed Fisher's exact test to test if the odds ratio is significantly greater than 1 


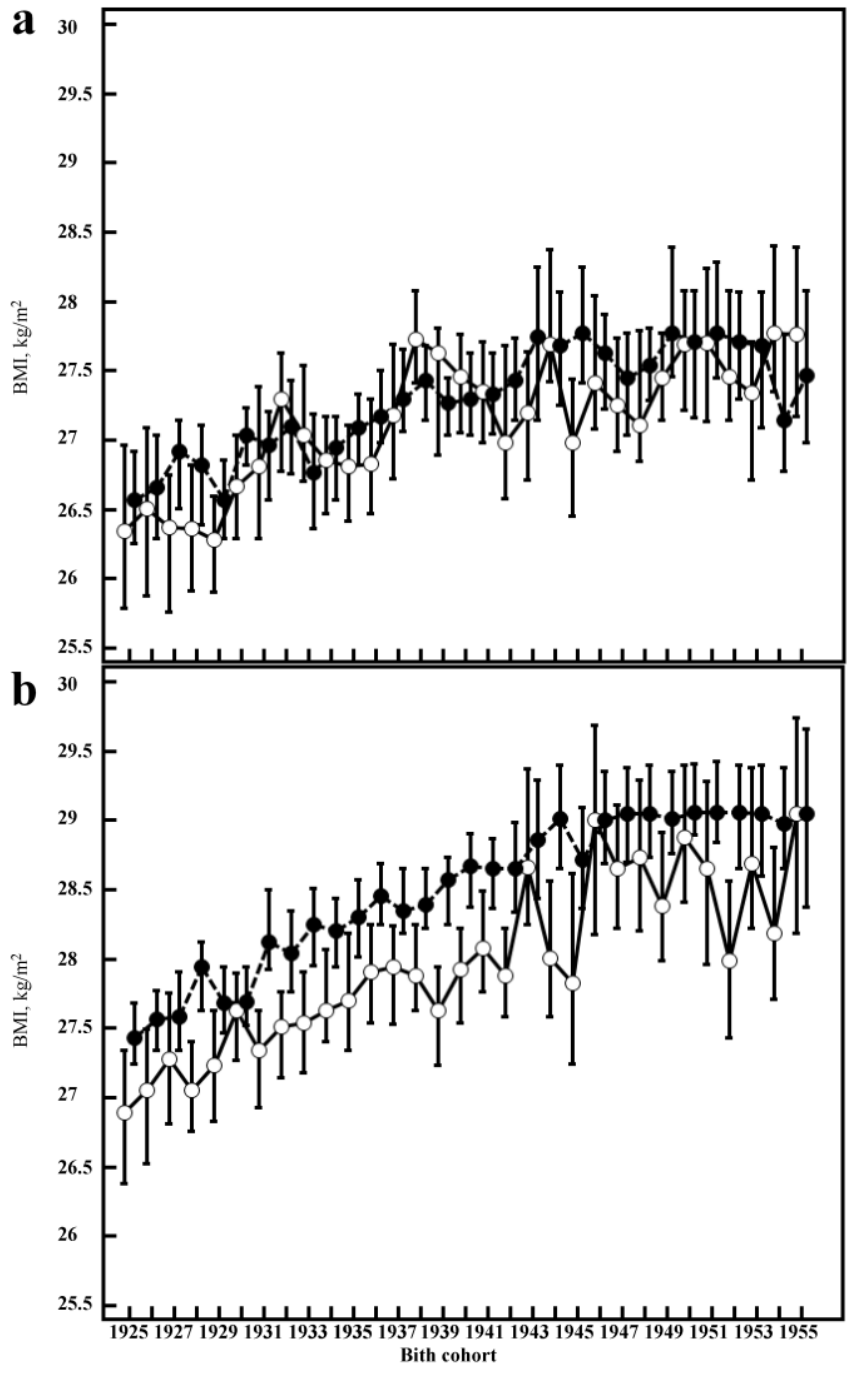

Fig. 3. Median values and $95 \%$ confidence intervals of body mass index in men (a) and women (b) with Type 2 diabetes, by birth cohort and region of residence. Open circles: Western Ukrainian populations (total $n=25$ 939); closed circles: Eastern Ukrainian populations (total $\mathrm{n}=68521$ ).

\section{Discussion}

High prevalence of T2D in several birth cohorts may likely be explained be adverse historical legacy in Ukraine population. Cohorts conceived before or during the Great Famine of 1932-33 and other famine episodes could be subjected to selection favoring the survival and reproduction of individuals with the thrifty genotype. Moreover, adaptations to early-life undernutrition could lead to metabolic and structural changes, which were beneficial for early survival, but might increase the risk of T2D in adulthood.

One possible explanation for the female predominance observed in most birth cohorts studied may be due to the fact that women are more likely than men to be influenced by adverse early-life conditions. For example, Ravelli et al. [25] comparing people exposed to Dutch famine 1944-45 in late, mid, or early gestation (exposed participants) with those born before or conceived after the famine period (nonexposed participants) have found that maternal malnutrition during early gestation was associated with higher BMI and waist circumference in 50-y-old women but not in men. The authors concluded these findings suggest that pertubations of central endocrine regulatory systems established in early gestation may contribute to the development of abdominal obesity in later life. In more recent study, exposure to the Dutch famine during gestation was strongly associated with a wide range of indexes of body mass distribution in middle-age women, but it was not associated with these indexes in men [26]. In women exposed to the Great Chinese Famine in utero or during early childhood, weight and BMI were significantly greater compared to those born after the famine; early-life exposure to famine had no effect on adult men's weight [27]. The results from the Leningrad study confirm that T2D without obesity develops earlier and more often in women but not in men exposed to the Siege of Leningrad during childhood [28]. These epidemiologic findings were confirmed by animal experiments. In some animal studies [29, 30], it has been shown the gender difference in the effect of intrauterine malnutrition. For instance, female adult rats exposed to intrauterine undernutrition had increased adiposity, marked impairment of hypothalamic insulin signaling, and loss of insulin-induced hypophagia. Such disturbances were less severe or even absent in male progeny [29]. These results led the authors to conclude that female progeny are more susceptible than their male siblings to the effects of maternal malnutrition. Thereby, the female predominance among the patients with T2D obtained in our study may be a result of adverse life conditions in Ukraine during the first half of the 20st century. The observation that female preponderance in Eastern Ukraine regions is evident in the older cohorts and it is more pronounced than that in Western Ukraine regions, perhaps, can be explained by the fact that Western Ukraine joined the Soviet Union only in 1939. Thereby, the Western Ukraine population was not exposed to a number of sociallyinduced disasters including the Great Famine of 1932-33 caused serious demographic losses (estimated at around 3-4 million persons) $[20,31]$. It is also noteworthy that, as we can see from Table 
2, female/male ORs are significantly higher in Eastern-Ukraine regions compared with WesternUkraine regions, except for Chernihiv region where $\mathrm{OR}$ is as low as in Western-Ukraine regions. Remarkably, the Famine of 1932-33 was far less severe in Chernigiv region compared with other Eastern-Ukraine regions [20]. Moreover, as we can see from Table 2, prevalence rates of T2D show a peak in the birth cohort 1930-34 in women residing in Crimea and Kherson regions $(9.0 \%$ and $9.2 \%$, respectively). These regions were much more liable to suffer from Famine of 1932-33 than other regions studied. An increased risk for T2D is consistently associated with higher BMI. One reason for the major impact of obesity on the development of T2D is that it often is accompanied by the metabolic syndrome, a cluster of hyperglycemia, dyslipidemia, and hypertension [32]. Our results regarding the regional differences in T2D prevalence are confirmed by BMI data. The inter-regional difference was evident for female but not male patients with T2D (Fig. 3). Among them, those women residing in Eastern Ukraine, an area suffered from severe famine in 193233, have higher BMI than those residing in Western Ukraine (non-exposed area).

A potential weakness of our study is that only 5 out of 25 Ukrainian regions were studied. However, in our recent study of BMI data of all insulin-treated T2D patients in Ukraine ( $\mathrm{n}=103$ 571, including 18508 persons residing in 6 Western Ukrainian regions and 85066 persons residing in 19 Eastern Ukrainian regions) a very similar trend was observed (unpublished data). Among the Western Ukrainian insulin-treated T2D women $(\mathrm{n}=10608)$, the mean BMI was 28.0 (95\%CI: 27.9 -28.09), and among the Eastern Ukrainian T2D women $(\mathrm{n}=55$ 031), BMI was 28.43 (95\%CI: 28.38-28.45), $\mathrm{p}<0.0001$. Among men the interregional difference in BMI was not significant: $26.63(95 \% \mathrm{CI}: 26.54-26.72)$; and 26.76 (95\%CI: 26.58-27.06) kg/m² mean BMI in Western $(\mathrm{n}=7897)$ and Eastern $(\mathrm{n}=30035)$ regions respectively, $\mathrm{p}=0.218$.

Weight gain in insulin-treated T2D patients is a well known phenomenon. Several studies have demonstrated that treating T2D patients with exogenous insulin results in an average increase of $3 \%$ to $9 \%$ over pretreatment body weight, depending on the length of the study and the intensity of glucose control $[38,39]$. Therefore, it is possible to explain the observed increase in BMI in women from the Eastern regions of Ukraine by the territorial and gender differences in the use of insulin for the treatment of T2D. Indeed, in the Western regions studied insulin used less frequently than in the Eastern ones (12.6\% and $17.6 \%$ respectively) for the T2D therapy, while the proportion of males among insulin-treated T2D was $41.6 \%(95 \%$ CI $32.9-34.6)$ in the Western and only $33.8 \%$ (95\% CI $32.9-34.6)$ in the Eastern regions of Ukraine studied. However, detection of similar trend in the analysis of entire population of insulin treated T2D patients $(\mathrm{n}=103$ 571) in Ukraine (unpublished data) indicates the independence of this phenomenon from the factor of the insulin treatment. The factor of ethnicity may be significant only for the multiethnic population of the Crimea, but confirmation of differences in BMI for insulin treated T2D women in 19 exposed and 6 non-exposed regions (unpublished data) is not confirmed the effect of ethnicity.

It must be noted that if we consider the Eastern regional cluster (famine affected) a "risk factor", vs the Western regional cluster (non famine affected), and female gender as the "outcome», the odds ratio would be 1.36 (95\% CI: $1.32-1.41) ; \mathrm{p}<0.001$.

Male preponderance among patients with T2D in the oldest age group ( $\leq 1924$ birth cohort) seems paradoxical because it contradicts the numerous epidemiological evidence that suggest that male cases outnumber female cases until age group 75-79, and from age groups 80 and older, T2D is more prevalent in female cases [33, 34]. One possible explanation for this observation is that diabetic women generally have a greater relative risk of cardiovascular diseases than diabetic men, and impact of diabetes on the risk of coronary death which is associated to stroke and heart attack is significantly greater for women than men in comparison with non-diabetic women and men [3537]. However it is not clear why male preponderance in oldest age group among T2D patients is only Ukraine phenomenon, and opposite tendency is evident in other countries. Further studies are necessary to clarify this issue.

Acknowledgements The authors are grateful to the Ukrainian Primary Care Doctors who have sent clinical data on their patients to the National Diabetes Mellitus Registry. Additional thanks to Volodymir Kovtun for technical assistance.

\section{References}

1.Rato Q. Diabetes mellitus: a global health problem. Rev Port Cardiol 2010;29:539-43.

2.Shaw JE, Sicree RA, Zimmet PZ. Global estimates of the prevalence of diabetes for 2010 and 2030. Diabetes Res Clin Pract 2010;87:4-14. http://dx.doi.org/10.1016/j.diabres.2009.10.007

3.Chmurzynska A. Fetal programming: link between early nutrition, DNA methylation, and complex diseases. Nutr Rev 2010;68:87-98. http://dx.doi.org/10.1111/j.1753-4887.2009.00265.x

4.Warner MJ, Ozanne SE. Mechanisms involved in the developmental programming of adulthood disease. Biochem J 2010;427:333-47. http://dx.doi.org/10.1042/BJ20091861 
5.Neel JV. Diabetes mellitus a "thrifty" genotype rendered detrimental by "progress"? Am J Hum Genet 1962;14:352-3.

6.Hales CN, Barker DJ. Type 2 (non-insulindependent) diabetes mellitus: the thrifty phenotype hypothesis. Diabetologia 1992;35:595-601. http://dx.doi.org/10.1007/BF00400248

7.Stöger R. The thrifty epigenotype: an acquired and heritable predisposition for obesity and diabetes? Bioessays 2008;30:156-66. http://dx.doi.org/10.1002/bies.20700

8.Pirola L, Balcerczyk A, Okabe J, et al. Epigenetic phenomena linked to diabetic complications. Nat Rev Endocrinol 2010;6:665-75. http://dx.doi.org/10.1038/nrendo.2010.188

9.Gale EA, Gillespie KM. Diabetes and gender. Diabetologia 2001;44:3-15. http://dx.doi.org/10.1007/s001250051573

10.Reddy KS. Cardiovascular disease in non-Western countries. N Engl J Med 2004; 350:2438-40. http://dx.doi.org/10.1056/NEJMp048024

11.Jafar TH, Chaturvedi N, Pappas G. Prevalence of overweight and obesity and their association with hypertension and diabetes mellitus in an IndoAsian population. CMAJ 2006;175:1071-77. http://dx.doi.org/10.1503/cmaj.060464

12.Luo W, Morrison $\mathrm{H}$, de Groh $\mathrm{M}$ et al. The burden of adult obesity in Canada. Chronic Dis Can 2007;27:135-44.

13.Roglic G. Diabetes in women: the global perspective. Int J Gynaecol Obstet 2009;104:S1113. http://dx.doi.org/10.1016/j.ijgo.2008.11.022

14.Kuh D, Power C, Blane D, et al. Social Pathways between Childhood and Adult Health. In: A Life Course Approach to Chronic Disease Epidemiology. Kuh D, Ben-Shlomo Y, eds. Oxford: Oxford University Press 1997: 169-98.

15.Tang M, Chen Y, Krewski D. Gender-related differences in the association between socioeconomic status and self-reported diabetes. Int J Epidemiol 2003;32:381-5.

http://dx.doi.org/10.1093/ije/dyg075

16.Rathmann W, et KORA Study Group. Sex differences in the associations of socioeconomic status with undiagnosed diabetes mellitus and impaired glucose tolerance in the elderly population: the KORA Survey 2000. Eur J Public Health 2005;15:627-33.

http://dx.doi.org/10.1093/eurpub/cki037

17.Ko GT, Chan JC, Yeung VT, et al. A low socioeconomic status is an additional risk factor for glucose intolerance in high risk Hong Kong Chinese. Eur J Epidemiol 2001;17:289-95. http://dx.doi.org/10.1023/A:1017935707807
18.Tian H, Song $\mathrm{G}$, Xie $\mathrm{H}$, et al. Prevalence of diabetes and impaired fasting glucose among 769,792 rural Chinese adults. Diabetes Res Clin Pract 2009;84:273-8. http://dx.doi.org/10.1016/j.diabres.2009.03.015

19. Tronko M, Khalangot M, Kravcenko V, et al. Gender distribution in Ukrainian adult insulintreated diabetics depending of age at diagnosis Endocr Abstr 2006;11:298.

20.Carynnyk M, Luciuk LY, Kordan BS, eds. The Foreign Office and the Famine. British Documents on Ukraine and the Great Famine of 1932-1933. Kingston, Ontario-Vestal, New York: The Limestone Press 1988.

21.Khalangot $\mathrm{M}$, Tronko $\mathrm{M}$, Kravchenko V, et al. Body mass index and the risk of total and cardiovascular mortality among patients with type 2 diabetes: a large prospective study in Ukraine. Heart 2009;95:454-60. http://dx.doi.org/10.1136/hrt.2008.150524

22.Distribution of Resident Population by Sex and Age. Statistical Yearbook. Kyiv: State Statistics Committee of Ukraine 2006.

23. Statistics with confidence. Confidence intervals and statistical guidelines. $2^{\text {nd }}$ ed. Altman DG, Machin D, Bryant TN, Gardner MJ, eds. Bristol: BMJ Books 2003.

24.Colagiuri S, Davies D. Diabetes-related risk factors in older people. In: Sinclair AJ, ed. Diabetes in Old Age, $3^{\text {rd }}$ ed. Oxford: John Wiley \& Sons, Inc. 2009: 13-18.

http://dx.doi.org/10.1002/9780470744093.ch2

25.Ravelli AC, van Der Meulen JH, et al. Obesity at the age of $50 \mathrm{y}$ in men and women exposed to famine prenatally. Am J Clin Nutr 1999;70:811-6.

26.Stein AD, Kahn HS, Rundle A, et al. Anthropometric measures in middle age after exposure to famine during gestation: evidence from the Dutch famine. Am J Clin Nutr 2007;85:869-76.

27.Wang Y, Wang X, Kong Y, et al. The Great Chinese Famine leads to shorter and overweight females in Chongqing Chinese population after 50 years. Obesity 2010;183:588-92. http://dx.doi.org/10.1038/oby.2009.296

28.Khoroshinina LP, Zhavoronkova NV. Starving in childhood and diabetes mellitus in elderly age. Adv Gerontol 2008;21:684-87 (in Russian).

29.Sardinha FL, Telles MM, Albuquerque KT et al. Gender difference in the effect of intrauterine malnutrition on the central anorexigenic action of insulin in adult rats. Nutrition 2006;22:1152-61. http://dx.doi.org/10.1016/j.nut.2006.07.002

30.Zambrano E, Bautista CJ, Deás M et al. A low maternal protein diet during pregnancy and 
lactation has sex- and window of exposure-specific effects on offspring growth and food intake, glucose metabolism and serum leptin in the rat. J Physiol 2006;571:221-30.

http://dx.doi.org/10.1113/jphysiol.2005.100313

31.Vallin J, Meslé F, Adamets $\mathrm{S}$, et al. A new estimation of Ukrainian losses during the 30 s and 40s crises. Population Studies 2002;56:249-64. http://dx.doi.org/10.1080/00324720215934

32.Arnlöv J, Sundström J, Ingelsson E, et al. Impact of BMI and the metabolic syndrome on the risk of diabetes in middle-aged men. Diabetes Care 2011;34:61-65.

33.Wild S, Roglic G, Green A, et al. Global prevalence of diabetes: estimates for the year 2000 and projections for 2030. Diabetes Care 2004;27:1047-53. http://dx.doi.org/10.2337/diacare.27.5.1047

34.Johnson JA, Vermeulen SU. Chapter 2 Epidemiological trends of diabetes in Alberta. In: Alberta Diabetes Atlas 2007. Edmonton: Institute of Health Economics 2007: 11-24.
35.Lee WL, Cheung AM, Cape D, et al. Impact of diabetes on coronary artery disease in women and men: a meta-analysis of prospective studies. Diabetes Care 2000;23:962-8. http://dx.doi.org/10.2337/diacare.23.7.962

36.Hu G; DECODE Study Group. Gender difference in all-cause and cardiovascular mortality related to hyperglycaemia and newly-diagnosed diabetes. Diabetologia 2003;46:608-17.

37.Venskutonyte L, Malmberg K, Norhammar A, et al. Effect of gender on prognosis in patients with myocardial infarction and type 2 diabetes. J Intern Med 2010;268:75-82.

38.Carver C. Insulin treatment and the problem of weight gain in type 2 diabetes. Diabetes Educ. 2006;32:910-7. http://dx.doi.org/10.1177/0145721706294259

39. Mudaliar S, Edelman S. Insulin therapy in type 2 diabetes. Endocrinology and Metabolism Clinics 2001;30:1-32. 